\title{
Chronic pain relief after the exposure of nitrous oxide during dental treatment: longitudinal retrospective study
}

\author{
Alívio da dor crônica após exposição ao óxido nitroso durante tratamento odontológico: \\ estudo retrospectivo longitudinal
}

Francisco Moreira Mattos Júnior', Rafael Villanova Mattos' ${ }^{1}$, Manoel Jacobsen Teixeira' ${ }^{1}$ Silvia Regina

Dowgan Tesseroli de Siqueira², Jose Tadeu Tesseroli de Siqueira ${ }^{3}$

\begin{abstract}
The objective was to investigate the effect of nitrous/oxygen in chronic pain. Seventy-seven chronic pain patients referred to dental treatment with conscious sedation with nitrous oxide/oxygen had their records included in this research. Data were collected regarding the location and intensity of pain by the visual analogue scale before and after the treatment. Statistical analysis was performed comparing pre- and post-treatment findings. It was observed a remarkable decrease in the prevalence of pain in this sample (only 18 patients still had chronic pain, $p<0.001)$ and in its intensity $(p<0.001)$. Patients that needed fewer sessions received higher proportions of nitrous oxide/oxygen. Nitrous oxide may be a tool to be used in the treatment of chronic pain, and future prospective studies are necessary to understand the underlying mechanisms and the effect of nitrous oxide/oxygen in patients according to the pain diagnosis and other characteristics.
\end{abstract}

Keywords: chronic pain, nitrous oxide, dental treatment, pain relief.

\section{RESUMO}

O objetivo deste estudo foi investigar o efeito do óxido nitroso na dor crônica. Os prontuários de 77 pacientes com dor crônica submetidos a tratamento odontológico com sedação consciente (óxido nitroso/oxigênio) foram incluídos. Os dados sobre localização e intensidade de dor pela escala visual analógica foram considerados, e foi realizada comparação e análise estatística entre os momentos pré- e pós-tratamento. Foi observada redução marcante na prevalência de dor nesta amostra (apenas 18 doentes ainda tinham dor, $p<0,001$ ) e na intensidade de dor $(p<0,001)$. Os doentes que precisaram de menor quantidade de sessões receberam maiores proporções de óxido nitroso/oxigênio. Em conclusão, pode-se considerar o oxido nitroso como uma ferramenta a ser investigada no tratamento da dor crônica em estudos futuros prospectivos, que poderão identificar os mecanismos associados de acordo com o diagnóstico de dor e outras características.

Palavras-chave: dor crônica, óxido nitroso, tratamento odontológico, alívio da dor.

Conscious sedation with nitrous oxide is a well-known method used for more than 100 years for dental treatment. Since 1976, it started to be used associated with oxygen and became more secure ${ }^{1}$. It helps in the control of anxiety and fear which play a role in acute pain perception, which wide application at the dental practice ${ }^{2,3}$.

Some of the observed effects of this type of sedation is the reduced need of analgesic drugs in the postoperative peri$\mathrm{od}^{4,5,6,7,8,9}$. Initially, nitrous oxide was considered an anesthetic drug, however these findings brought an evidence of an analgesic effect ${ }^{7,89}$. This effect meant reduced doses of analgesic drugs after several types of surgeries ${ }^{8}$, and it was considered a

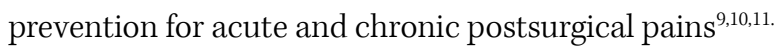

The antalgic efficacy of nitrous oxide in acute pain models have been investigated since that ${ }^{12,13,14,15}$. On the other side, chronic pain is described as 'pain for more than 6 months' by the International Association for the Study of Pain ${ }^{16}$. Only recently, a review showed that nitrous oxide can be a tool in the prevention of chronic pain development, but little is known about its effect in preexistent chronic pain conditions ${ }^{17}$.

A study from 5 years ago showed persistent pain alleviation in a neuropathic pain model by a single exposure

\footnotetext{
${ }^{1}$ Universidade de São Paulo, Faculdade de Medicina, Departamento de Neurologia, Sao Paulo SP, Brazil;

Universidade de São Paulo, Faculdade de Artes, Ciências e Humanidades, Sao Paulo SP, Brazil;

${ }^{3}$ Universidade de São Paulo, Faculdade de Medicina, Hospital das Clínicas, Clínica de Dor Orofacial, Sao Paulo SP, Brazil.

Correspondence: Silvia Regina Dowgan Tesseroli de Siqueira; Rua Maria Candida, 135; 02071-010 Sao Paulo SP, Brasil; E-mail: silviadowgan@hotmail.com

Conflict of interest: There is no conflict of interest to declare.

Received 15 December 2014; Received in final form 13 February 2015; Accepted 05 March 2015.
} 
to nitrous oxide/oxygen in $\operatorname{rats}^{18}$. This finding and the clinical observations are promising, and the effect and mechanisms of pain alleviation by nitrous oxide need further investigation.

Thus, the objective of this study was to investigate the effect of nitrous/oxygen in chronic pain of patients that were under dental treatment.

\section{METHOD}

\section{Subjects}

The dental profiles of 77 patients were included in this longitudinal retrospective research. They had been treated at the dental office under conscious sedation with nitrous oxide/oxygen March 2003 and April 2010. These patients were included because they presented in their anamnesis complaint of chronic pain in some part of their body for more than 6 months, which was part of their medical history. They had complete profiles including the location and intensity of pain by the visual analogue scale, which had been aplied immediately before and immediately after the complete dental treatment. The patients that needed more than one session of sedation had their pain measured before the first session and after the last one. The duration of pain relief was not assessed.

The patients were $43(44.8 \%)$ women and the mean age was $58.1 \pm 10.6(20-83)$ years old. This study was approved by the Ethics Committee of our institution.

\section{Dental treatments and conscious sedation}

All patients had been evaluated and treated by the same trained dentist. The treatment included dental extractions, endodontic treatment, surgeries, periodontal scalling and all received information about oral hygiene. The mean number of dental sessions was $3.9 \pm 2.6$ (1-11). The interval between the sessions was $2-3$ days. The mean nitrous oxide proportion was $2.5 \pm 0.6$ units and the mean oxygen proportion was $3.7 \pm 0.7$ units. All had their arterial blood pressure, heart rate and oxygen rate monitored during conscious sedation. The portable gases mixture was equipped with a sound system that avoided inadequate dosage of nitrous oxide (higher than oxygen).

Initially, the mask to administrate the gases was placed at the face of the patient. The proportions of nitrous oxide/oxygen were applied considering the following safety parameters and the individual variability of sensitivity to this technique: the majority of cases are able to inhale $50 \%$ of each $(3 \mathrm{~L} / \mathrm{min}$ of nitrous oxide and $3 \mathrm{~L} / \mathrm{min}$ oxygen), part of patients are able to inhale $33 \%$ (2 L/min nitrous oxide and $4 \mathrm{~L} / \mathrm{min}$ oxygen) and few patients are able to inhale only $16.7 \%$ ( $1 \mathrm{~L} / \mathrm{min}$ nitrous nitrous oxide and $5 \mathrm{~L} / \mathrm{min}$ oxygen). All procedures started with $6 \mathrm{~L} / \mathrm{min}$ of oxygen and after each 3 minutes, $1 / 2 \mathrm{~L} / \mathrm{min}$ of nitrous oxide was increased. The report by the patient of peripheral tingling (hands and feet) and or the blood parameters were the factors to determine the interruption in the increase of nitrous oxide proportions, and the limit was $3 \mathrm{~L} / \mathrm{min}$ nitrous oxide to $3 \mathrm{~L} / \mathrm{min}$ oxygen. After the dental treatment, the proportion of nitrous oxide was gradually reduced until only oxygen was administered for 3 to 5 minutes and the patients reported no symptoms of sedation. During all the procedure, the patients remained conscious with the protective reflexes (swallowing and cough), breathing, sensation of physical stimuli and talking with the dentist.

\section{Statistical analysis}

The sample consisted of all patients from a dental clinic that had been treated with conscious sedation with nitrous oxide/oxygen. All data were tabled and the means, standard deviations, frequencies and percentages were computed. After the initial descriptive analysis, the data were tested with Shapiro-Wilk e QQ plots in order to investigate normal distribution. The tests used for associations and differences between pre and post treatment data were oneway ANOVA, Student's, chi-square and Wilcoxon. Correlations were investigated with the Pearson's coefficient. All statistical calculations were performed using SPSS 17.0 (SPSS Inc.,Illinois,USA). The level of significance was $\mathrm{p}<0.05$.

\section{RESULTS}

There was a decrease in the number of patients with pain complaints and in the intensity, which can be observed in Tables 1 and 2. The female gender was associated with the decrease in the number of patients with pain at the head (chi-square, $p=0.005$ ), abdomen (chi-square, $p=0.002$ ) and inferior or superior limbs (chi-square, $p=0.001$ ).

Table 1. Pain complaint and location before and after the dental treatment with sedation (number of patients with complaints) ( $\mathrm{N}=77$ ).

\begin{tabular}{|c|c|c|c|}
\hline & Before the dental treatment & After the dental treatment & p-value* \\
\hline Pain in any body part & $77(100.0 \%)$ & $18(23.4 \%)$ & $<0.001$ \\
\hline Head and/or neck pain & $28(36.4 \%)$ & $4(5.2 \%)$ & 0.015 \\
\hline Pain at thorax, back and/or abdomen & $43(55.8 \%)$ & $10(13.0 \%)$ & 0.002 \\
\hline Superior limbs pain & $22(28.6 \%)$ & $8(10.4 \%)$ & $<0.001$ \\
\hline Inferior limbs pain & $30(39.0 \%)$ & $6(7.8 \%)$ & 0.003 \\
\hline
\end{tabular}

*Pearson's chi-square; Fisher's exact test; Wicoxon test. 
Table 2. Pain intensity according to the location before and after the dental treatment with sedation $(\mathrm{N}=77)$.

\begin{tabular}{lccc}
\hline & Before the dental treatment & After the dental treatment & $p$-value* \\
\hline Mean** & $7.5 \pm 2.1(0-10)$ & $0.7 \pm 0.7(0-7)$ & $<.001$ \\
Head and/or neck** & $7.5 \pm 2.0(3-10)$ & $0.2 \pm 0.2(0-2)$ & $<.001$ \\
Thorax, back and/or abdomen** & $7.4 \pm 2.5(0-10)$ & $0.6 \pm 0.6(0-4)$ & $<.001$ \\
Superior limbs** & $7.4 \pm 2.2(2-10)$ & $1.4 \pm 1.0(0-10)$ & $<.001$ \\
Inferior limbs** & $8.0 \pm 1.8(4-10)$ & $0.8 \pm 0.6(0-7)$ & $<0.001$ \\
\hline
\end{tabular}

*One-way ANOVA; paired samples T-test; **Pain intensity according to the visual analogue scale.

\section{Correlations}

The decrease in pain intensity after the treatment with sedation was higher in patients that were older (Pearson's coefficient, $\mathrm{p}=0.015$ ). Patients with body pain and high intensity showed more dental pain during treatment and needed high proportion of nitrous oxide (Pearson's coefficient, $p=0.037$ ). Finally, patients that needed few sessions received high proportions of nitrous oxide/oxygen (Figure).

\section{DISCUSSION}

This study showed evidence of remarkable reduction of chronic body pain complaints in patients that underwent dental treatment with conscious sedation with sedation with nitrous oxide/oxygen. This reduction was not associated with the location of pain, but according to the gender and ages. Women had more pain relief than men, and the older patients had higher decrease in pain intensity than the younger ones.

The doses of analgesic drugs can be reduced after the use of nitrous oxide during surgical procedures $\mathrm{s}^{4,5,6,7,8,9,10,11,12,13,14}$. The development of chronic pain after surgeries can also be prevented with this type of sedation ${ }^{17}$. However, this is the first study that had showed the effect of nitrous oxide in pain alleviation of chronic symptoms and not in the use as intraoperative anesthetic technique $\mathrm{e}^{10,11,12,13,14,15,16,17}$.

The mechanism underlying the analgesic effect of nitrous oxide seems to be its role as an antagonist at the $\mathrm{N}$-methyl-D-aspartate receptor, involved in pain chronification ${ }^{11}$. Patients with chronic pain show neuroplastic phenomena and altered neural processing that involves NMDA receptors, and they can be a target for anesthesia and analgesic effect that are systemic. In rats, a single exposure to nitrous oxide sedation was capable of alleviate neuropathic pain for a long period, including the reduction of thermal allodynia ${ }^{10,18}$. Thus, nitrous oxide could be a tool in the treatment of chronic pain conditions.

Nitrous oxide has been used in dentistry since the XIX century for analgesia and it is a safe and effective technique for the control of anxiety and fear. It has been shown that women at labor had less pain and fewer analgesics consume after delivery when exposed to it ${ }^{19}$. Its use is regulated and the equipment must prevent proportions higher than $70 \%$ of $\mathrm{N}^{2} \mathrm{O}$. Besides its effect in NMDA receptors, the nitrous oxide may cause a release of endorphins and dopamine that modulate

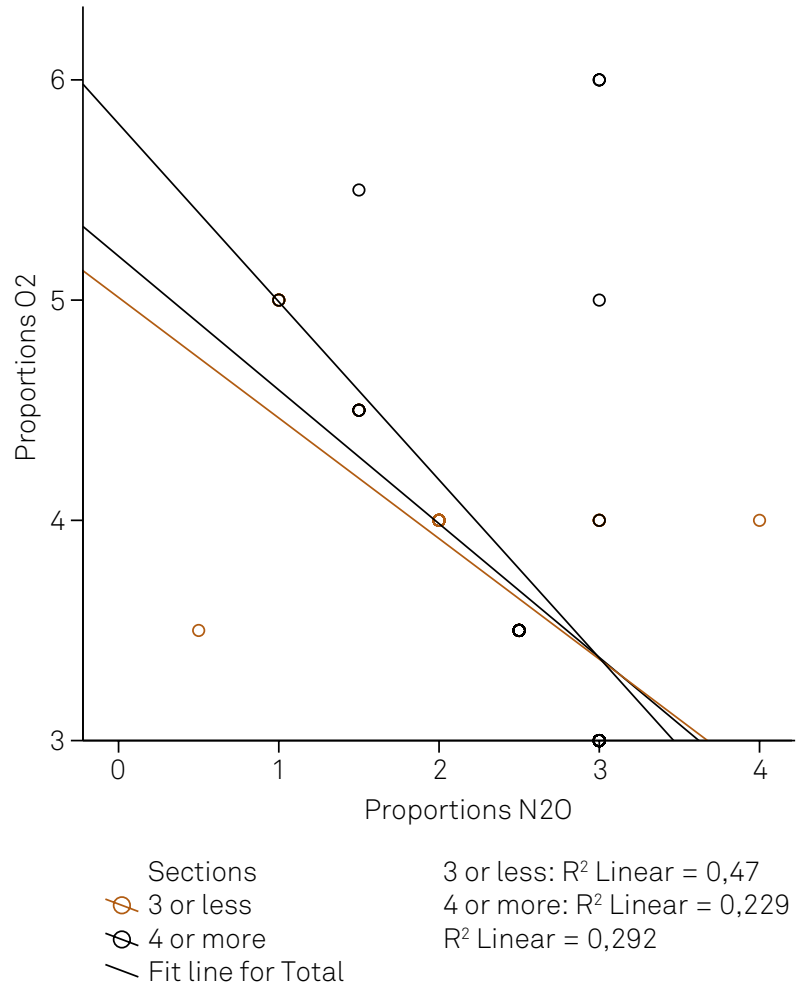

Figure. Negative correlation between the proportion of nitrous oxide / oxygen and the number of sessions (Pearson's coefficient, $p=0.026$ ).

the suppressive descendent pathways, however it seems that the relief of chronic neuropathic pain in rats was more associated with the antagonic effect on NMDA receptors ${ }^{18}$. More studies are necessary to clarify the exact pathophysiological mechanism in chronic pain patients, according to the diagnosis, establishing if they are the same as the relief in acute postsurgical pain by nitrous oxide ${ }^{19,20}$. The role of sexual hormones, genetic differences and aging need to be also investigated in order to understand the associations found. Finally, the patients that were exposed to low proportions of nitrous oxide needed more sessions for the dental treatment, and it is possible that there was a lack in the analgesic effect because of concentration that turned into necessary new appointments to finish the treatment. Therefore, future prospective studies are necessary.

Some limitations of the application need to be further investigated. The sedation with nitrous oxide may be associated with the long-term risk of myocardial infarction, and thus 
the patients need to be carefully evaluated in order to indicate this sedation only for those with none or low risks due to this technique ${ }^{1,18}$. In elderly, other risks such as cancer recurrence, neurotoxicity and long-term cognitive dysfunction need to be investigated and considered.

In conclusion, chronic pain at other parts of the body of patients that underwent dental treatment with nitrous oxide sedation presented a reduction in their intensity. It was not dependent on the local of pain and more often in women. Nitrous oxide may be a tool to be used in the treatment of chronic pain, and future prospective studies are necessary to understand the underlying mechanisms and the effect of nitrous oxide/oxygen in patients according to the pain diagnosis and other characteristics.

\section{References}

1. Szymańska J. Environmental health risk of chronic exposure to nitrous oxide in dental practice. Ann Agric Environ Med. 2001;8(2):119-22.

2. Brunick A, Clark M. Nitrous oxide and oxygen sedation: an update. Dent Assist. 2010;79:22-3, 26, 28-30; quiz 32, 34.

3. Daher A, Hanna RP, Costa LR, Leles CR. Practices and opinions on nitrous oxide/oxygen sedation from dentists licensed to perform relative analgesia in Brazil. BMC Oral Health. 2012;12(1):21. http://dx.doi.org/10.1186/1472-6831-12-21

4. Echevarría G, Elgueta F, Fierro C, Bugedo D, Faba G, Iñiguez-Cuadra $\mathrm{R}$ et al. Nitrous oxide $(\mathrm{N}(2) \mathrm{O})$ reduces postoperative opioid-induced hyperalgesia after remifentanil-propofol anaesthesia in humans. $\mathrm{Br}$ J Anaesth. 2011;107(6):959-65. http://dx.doi.org/10.1093/bja/aer323

5. Stiglitz DK, Amaratunge LN, Konstantatos AH, Lindholm DE. Intraoperative nitrous oxide as a preventive analgesic. Anaesth Intensive Care. 2010;38(5):890-3.

6. Soumpasis I, Kanakoudis F, Vretzakis G, Arnaoutoglou E, Stamatiou $\mathrm{G}$, latrou C. Deep anaesthesia reduces postoperative analgesic requirements after major urological procedures. Eur J Anaesthesiol. 2010;27(9):801-6. http://dx.doi.org/10.1097/EJA.0b013e328337cbf4

7. Yuxiang L, Lu T, Jianqiang Y, Xiuying D, Wanfang Z, Wannian Z et al. Analgesia effect of a fixed nitrous oxide/oxygen mixture on burn dressing pain: study protocol for a randomized controlled trial. Trials. 2012;13(1):67. http://dx.doi.org/10.1186/1745-6215-13-67

8. Duma A, Helsten D, Brown F, Bottros MM, Nagele P. The effect of nitrous oxide anesthesia on early postoperative opioid consumption and pain. Reg Anesth Pain Med. 2014;39(1):31-6. http://dx.doi.org/10.1097/AAP.0000000000000039

9. Ko H, Kaye AD, Urman RD. Nitrous oxide and perioperative outcomes. J Anesth. 2014;28(3):420-8. http://dx.doi.org/10.1007/s00540-013-1729-y

10. Chan MT, Wan AC, Gin T, Leslie K, Myles PS. Chronic postsurgical pain after nitrous oxide anesthesia. Pain. 2011;152(11):2514-20. http://dx.doi.org/10.1016/j.pain.2011.07.015

11. Kavanagh T, Buggy DJ. Can anaesthetic technique effect postoperative outcome? Curr Opin Anaesthesiol. 2012;25(2):185-98. http://dx.doi.org/10.1097/AC0.0b013e32834f6c4c
12. Del Valle Rubido C, Solano Calvo JA, Miguel AR, Delgado Espeja JJ, González Hinojosa J, Zapico Goñi Á. Inhalatory analgesia with nitrous oxide vs. other analgesic techniques in hysteroscopic polypectomy: pilot study. J Minim Invasive Gynecol. Forthcoming 2015.

13. Yokoe C, Hanamoto H, Sugimura M, Morimoto Y, Kudo C, Niwa H. A prospective, randomized controlled trial of conscious sedation using propofol combined with inhaled nitrous oxide for dental treatment. J Oral Maxillofac Surg. 2015;73(3):402-9. http://dx.doi.org/10.1016/j.joms.2014.09.014

14. Manouchehrian N, Bakhshaei MH. Nitrous oxide effect on relieving anxiety and pain in parturients under spinal anesthesia for caesarean section. Anesth Pain Med. 2014;4(2):e16662. http://dx.doi.org/10.5812/aapm.16662

15. Sun WZ. Anesthetic or analgesic effect of $\mathrm{N}_{2} \mathrm{O}$ in acute pain model? Reg Anesth Pain Med. 2014;39(3):263. http://dx.doi.org/10.1097/AAP.0000000000000081

16. Merskey $\mathrm{H}$, Bogduk N, editors. Classification of chronic pain: descriptions of chronic pain syndromes and definitions of pain terms. 2nd ed. Seattle: International Association for the Study of Pain; 1994.

17. Chaparro LE, Smith SA, Moore RA, Wiffen PJ, Gilron I. Pharmacotherapy for the prevention of chronic pain after surgery in adults. Cochrane Database Syst Rev. 2013;7:CD008307. http://dx.doi.org/10.1002/14651858.CD008307.pub2

18. Bessière B, Laboureyras E, Chateauraynaud J, Laulin JP, Simonnet G. A single nitrous oxide (N2O) exposure leads to persistent alleviation of neuropathic pain in rats. J Pain. 2010;11(1):13-23. http://dx.doi.org/10.1016/j.jpain.2009.05.003

19. Klomp T, van Poppel M, Jones L, Lazet J, Di Nisio M, Lagro-Janssen AL. Inhaled analgesia for pain management in labour. Cochrane Database Syst Rev. 2012;9:CD009351. http://dx.doi.org/10.1002/14651858.CD009351.pub2

20. Nesek-Adam V, Rasić Z, Schwarz D, Grizelj-Stojcić E, Rasić $D, K$ rstonijević $Z$ et al. The effect of spinal versus general anesthesia on postoperative pain and analgesic requirements in patients undergoing peripheral vascular surgery. Coll Antropol. 2012;36(4):1301-5. 